\title{
Graciliano Ramos: lembranças tangenciais
}

\author{
JACOB GORENDER
}

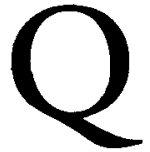

uando recebi o convite para participaçáo neste painel, perguntei-me acerca das credenciais de que dispunha para falar de Graciliano Ramos, ao lado de especialistas de teoria literária como Alfredo Bosi, Boris Schnaiderman e Zenir Campos Reis, sendo eu alheio à matéria. Aceitei o convite porque cheguei à conclusão de que possuía credenciais, talvez não tão importantes, mas, em todo caso, justificativas da minha presença a estea mesa.

Sou, aqui, o único a ter tido conhecimento pessoal de Graciliano, o que derivou da circunstância de termos sido militantes, ambos, do mesmo partido político, o PCB - Partido Comunista do Brasil (a partir de 1961, denominado Partido Comunista Brasileiro). Ao que se acresce o fato de também ter passado pela experiência da cadeia, o que me permite fazer a leitura de Memórias do cárcere - objeto especial do nosso painel - apoiado em referências vivenciais.

No final de 1946, transferi-me de Salvador para o Rio de Janeiro, onde me tornei redator de $A$ classe operária, semanário do $\mathrm{PCB}$. Jovem provinciano, sentia o fascínio da cidade então realmente maravilhosa, conforme canção hoje esquecida. Vez por outra, à tardinha, ia à redação da Tribuna Popular, jornal diário do PCB, que ocupava um andar de edifício situado na Esplanada do Castelo. Ali, deslumbrava-me ao topar com Álvaro Moreyra, cronista do jornal, afável e loquaz; com sua mulher Eugênia Álvaro Moreyra, de vestido até os joelhos (a moda da época baixava-os até o meio da canela das pernas), cabelo à la garçonne e fumando charutinhos (espantoso !); e ainda Cândido Portinari, Graciliano, Jorge Amado e, mais raramente, Carlos Drummond de Andrade. Em torno das celebridades, formavam-se rodinhas de redatores e freqüentadores da redação. Metia-me no meio delas, escutava o que se conversava, limitando-me somente a ouvir. Eram agradáveis bate-papos informais, mas, passados tantos anos, não me recordo de nada do que se disse naquelas ocasióes.

Não demoraria para que entrasse em contato mais próximo com Graciliano. Em maio de 1947, o PCB sofreu a cassação do registro de partido legal. A repressão policial, que se seguiu, era branda, se comparada com o furor do regime militar pós-64, mas os órgãos partidários estavam obrigados a atuar na clandesti- 
nidade. As reuniốes precisavam ser realizadas de maneira secreta, sem dar na vista. Fui designado membro da Comissão Nacional de Agitação e Propaganda, da qual era responsável principal Maurício Grabois, membro da alta direção do partido. Nos anos setenta, comandou a guerrilha do Araguaia e morreu em combate, cujas circunstâncias são desconhecidas. A Comissão de Agitprop reunia-se em vários locais. Um deles, a residência de Graciliano, um apartamento na rua General Glicério, bairro de Laranjeiras. Recordo que ali, em 1949, fizemos três ou quatro reuniōes noturnas.

Seguindo a regra das medidas de segurança, os participantes da reuniáo não chegavam ao local ao mesmo tempo. Cada um tinha sua hora de bater à porta, o que devia cumprir com absoluto rigor. Enquanto chegávamos e esperávamos o último compromissado a entrar, Graciliano se entretinha conosco. Muito à vontade, sem o mínimo de pose, em momento algum preocupado com sentenças magistrais. Não me lembro de nada que tenha então ouvido dele, mas me ficou a memória de um homem aberto, acessível, sem ser o que se chama um falador. Nunca ria às gargalhadas, mas não era sombrio. Se a conversa entrava numa piada obscena, sua contribuição se inseria com a maior naturalidade. As reuniôes no apartamento das Laranjeiras deram oportunidade a que viesse também a conhecer sua mulher, Heloísa Ramos, e seu filho Ricardo.

Àquela altura, Graciliano já havia publicado todos os livros que, ao lado de Machado de Assis e de Guimarães Rosa, o colocam entre os maiores prosadores da literatura brasileira. Só faltava precisamente Memórias do cárcere. Contudo, não era diante de nós uma estátua, mas um companheiro, um igual, todos envolvidos no risco da militância clandestina.

Naqueles contatos, chamou-me a atenção um detalhe que terá seu lugar nas Memórias. Creio que nunca vi Graciliano sem um cigarro entre os dedos, cigarro de fumo forte. Em resposta a uma série de quesitos (Auto-retrato aos 56 anos, por João Condé), informou que fumava três maços por dia. Morreu de câncer do pulmão e cabe supor que em conseqüência do vício. Nas Memórias, são numerosas as referências à preocupação com a reserva de cigarros, com o estoque disponível, como será possível adquiri-los, enfrentando as condições adversas da vida de prisioneiro. Uma obsessão que pessoalmente entendo, porque, até há cerca de vinte anos, também carecia da dose diária de nicotina, embora raramente consumisse um maço a cada dia.

A fim de compreender as Memórias do cárcere, necessita-se esclarecer as relações do autor com o PCB. A imprensa anuncia dois livros biográficos, um deles, de publicação póstuma, escrito por Ricardo Ramos. Certamente, tratarão do assunto e o explicarão melhor do que eu. Advirto, pois, não pretender aqui apresentar mais do que lembranças tangenciais sobre o grande romancista. 
Quando o prenderam em 1936, em Maceió, Graciliano não era membro do partido comunista. Possivelmente, pelo que se pode inferir das Memórias, e também de Angristia, ele seria procurado por alguns dentre os pouquíssimos membros do partido na capital alagoana. Homem culto, ateu, Graciliano, como afirma em resposta aos já mencionados quesitos, odiava a burguesia e o capitalismo. Mas não participava de ações políticas práticas. Sua prisão foi inteiramente arbitrária, própria do ambiente da época, imediatamente posterior ao esmagamento dos levantes da Aliança Nacional Libertadora de novembro de 1935. Não é improvável que o escritor tivesse sido vítima de calúnias, de delações de pessoas atropeladas por sua integridade, no exercício das funções de prefeito de Palmeira dos Índios e de diretor da Instrução Pública do Governo de Alagoas.

Em 1945, o partido comunista ganhou estatuto legal e Graciliano filiou-se a ele juntamente com uma constelação de astros da cultura brasileira. Não pou$\cos$, nos anos seguintes, afastaram-se do partido. Graciliano permaneceu militante comunista até a morte. Não teve atritos com a direção comunista por motivos literários, senão em 1952 e 1953. No ano em que se filiou, aparece à luz Infáncia. Em 1947, a publicação da coletânea de contos Insónia encerra a produção do autor como ficcionista. Tal circunstância poupou o escritor de confrontos com a direção do partido, preconizadora do chamado realismo socialista. Posição que se enrijeceu a partir de 1950, quando a direção se arrogou o direito de censura prévia da produção literária dos militantes intelectuais. Como se sabe, os escritores submetiam-se obrigatoriamente à censura prévia na extinta União Soviética $\mathrm{e}$ nos demais países do Leste Europeu. Nos anos cinqüenta, exercia a função de censor-mor Diógenes de Arruda, segundo personagem na hierarquia dirigente, stalinista distinguido por insolente ignorância. Com Arruda e seus acólitos é que Graciliano iria defrontar-se nos últimos anos de vida. Conflito que se agravou após sua morte, quando se tratou da publicação póstuma de suas duas últimas obras. Mas antes de abordar a questão da censura comunista, devo fazer uma digressão a fim de referir-me à censura estado-novista, à qual aludiu o próprio Graciliano.

Ao iniciar as Memórias do cárcere, o autor explica o por quê de só ter começado a redação dez anos após sua prisão. Exclui, enquanto motivo para a demora, a censura prévia de obras de arte, que teria inexistido sob o Estado Novo. Afirmação a ser qualificada. O governo ditatorial dispensava a censura prévia, uma vez que as editoras praticavam a autocensura. $\mathrm{E}$ o faziam os próprios autores, nos quais, segundo Graciliano, se suprimia até o próprio desejo de produzir. Os jornais, disciplinados pelo Departamento de Imprensa e Propaganda (DIP), também não estavam sujeitos à censura prévia, porém seus diretores eram freqüentemente alertados sobre o que interessava ou estava proibido publicar. Jornais indisciplinados, comumente por faccionismos regionais, não escapavam da censura prévia. Eu mesmo, trabalhei num diário de Salvador, em 1940 - $O$ 
imparcial, já desaparecido -, o qual tinha um censor plantado na redação, com poder de veto sobre os textos antes de descerem à oficina de impressão. Também fui redator e secretário, em 1942-1943, da revista mensal Seiva, editada em Salvador, sob a direção de João da Costa Falcão, que contava com a colaboração de intelectuais no nível de Afrânio Coutinho, Hermes Lima, Orlando Gomes e Luiz Vianna Filho. A revista, de intençôes literárias, estava obrigada a submeter todas 'as matérias a um censor, ao qual pertencia a prerrogativa de autorizar ou não sua publicação. Por conseguinte, cumpre deixar claro que houve censura em geral no Estado Novo e, particularmente, também censura prévia, à medida em que convinha às autoridades da ditadura getulista. Graciliano pretendeu explicar o comportamento pessoal e da sua visão muito restrita resultou uma apreciação ambígua.

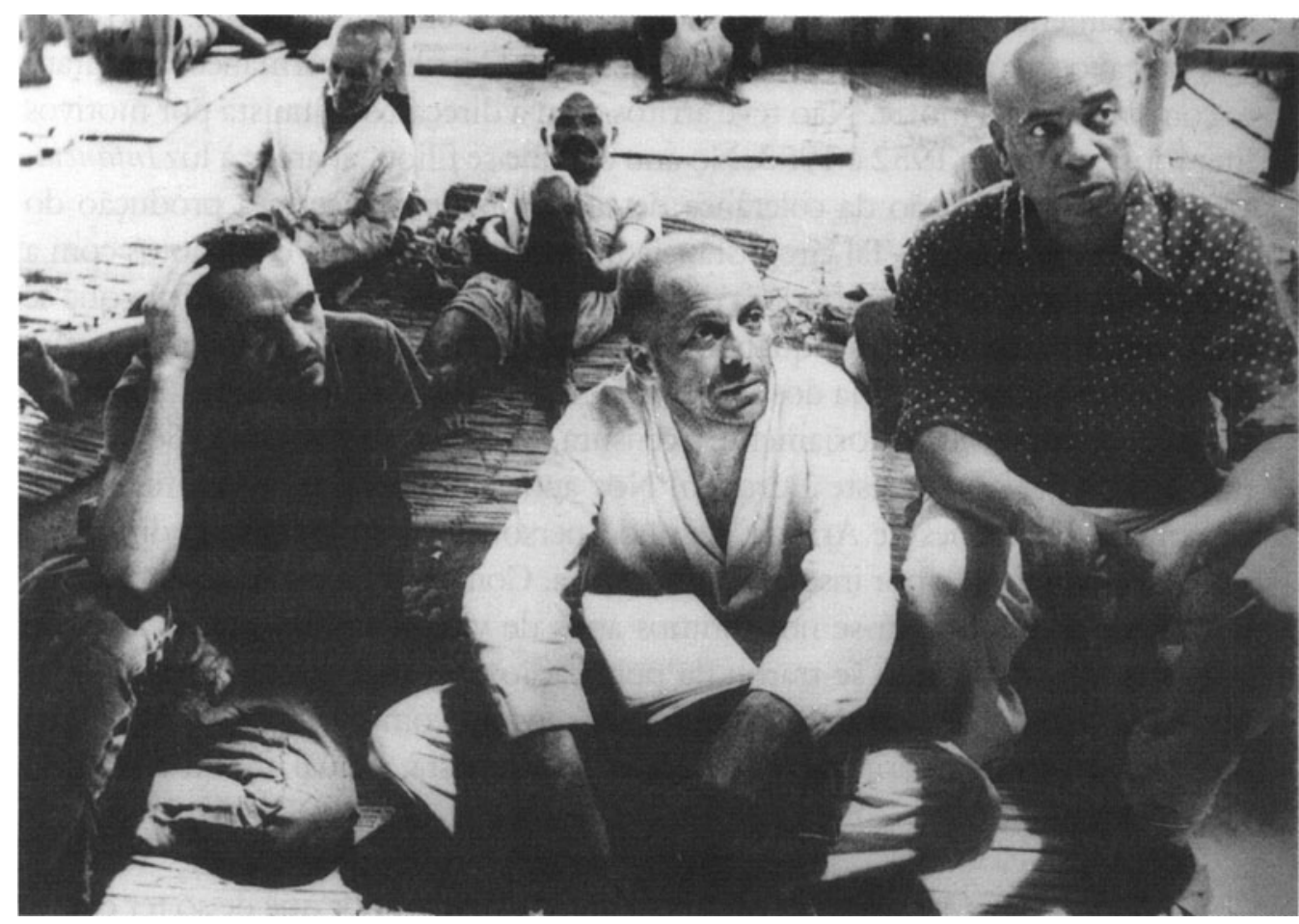

José Dumont, Carlos Vereza (Graciliano Ramos) e Waldyr Onofre no filme Memórias do Cárcere, de Nelson Pereira dos Santos

Voltemos à censura comunista. Em 1952, Graciliano fez parte de uma delegação de intelectuais brasileiros qué visitou a União Soviética. A viagem, que incluiu outros países, ganhou relato num livro, cuja importância pode ser considerada secundária na bibliografia do autor. Ainda assim, não lhe falta a habitual perfeição do estilo e sobram observaçóes saborosas. O livro, contudo, desagradou aos dirigentes comunistas. Por quê? Graciliano se confessou admirador da União Soviética e de Stálin, visto em pessoa no mausoléu de Lênin, na Praça Vermelha, por ocasião de uma festividade. Mas o escritor, sempre comedido, não 
tratou o famigerado déspota como se fosse um titã, um supergênio, conforme a praxe da propaganda comunista da época. Demais, vez por outra, sobre questóes importantes ou de detalhe, fez comentários críticos ou jocosos, inclusive a seu próprio respeito. Na verdade, o livro de viagem desagradou aos censores do partido comunista, porque não adotou a retórica da exaltação de péssimo gosto exigida dos intelectuais militantes.

Muito mais áspera teria de ser a divergência, quando se tratou de Memórias do cárcere, em 1953. Graciliano reproduz os fatos vivenciados e observados apoiado nas recordações, sem contar com as anotaçóes perdidas. $O$ tom da narrativa é realista, às vezes naturalista. Ausência completa de hagiografia. Os personagens não são mencionados com pseudônimos, mas recebem os nomes verdadeiros e ninguém é apresentado como santo, destituído de defeitos ou imune a fraquezas e tentaçóes. $\mathrm{O}$ autor escreve sobre a bravura dos bravos e atribui coragem aos corajosos. Porém todos são seres cọm virtudes e defeitos, figuras que não ultrapassam a condição do gênero humano. Ninguém é super-homem.

Numa época em que a exaltação hiperbólica estava na moda, o tratamento sóbrio ou mesmo irreverente dado a personagens conhecidos não podia deixar de irritar os dirigentes do partido. Um deles comentou comigo: "Veja só, o Graciliano escreve que o Agildo tem voz fina." Não confere exatamente com o que se lê. A referência é à voz fraca do ex-capitão do Exército, comandante - a 27 de novembro de 1935 - da insurreição do regimento da Praia Vermelha. Quando subia de tom, a voz de Agildo soava aflautada, em falsete. Ao ouvir um discurso de Agildo à assembléia dos presos políticos, concitando-os a reagir às arbitrariedades dos carcereiros, o memorialista anota que a fala do orador parecia um miar de gatos. Graciliano reproduz uma impressão de muitos que sabiam da fama do herói de 35 e vieram a conhecê-lo pessoalmente. Ficávamos surpresos que o homem com tão extraordinário currículo de lutas fosse um tampinha, baixote, magricela e de voz de contra-tenor. No entanto, nunca faltou a Agildo Barata o impulso da bravura física. Não temia atracar-se com adversários muito mais corpulentos do que ele. Graciliano narra diversos episódios, que dão relevo à valentia daquele indivíduo de estatura pequena, de aparência insignificante, porém tão capaz de liderar e de fazer-se estimado.

Em várias passagens, o autor menciona com simpatia o companheiro de cadeia Febus Gikovate. Mas este, por ser militante trotskista, sofria hostilidades e discriminações por parte da grande maioria dos encarcerados, sob influência da campanha stalinista contra Trotski. Em 1936, Graciliano não era membro do partido comunista e não devia obediência à orientação de Moscou. Mas redigindo já como membro do partido, dez anos depois, manteve-se fiel aos registros da memória, à sua sensibilidade estética, psicológica e moral, ao compromisso supremo com a verdade. Por isso mesmo, condenou as discriminações impostas a 
Gikovate pelos próprios presos políticos. Não demorou muito tempo para que o conhecimento da falsificação praticada pelo déspota do Kremlin confirmasse que não falhou a intuição do escritor ao rejeitar o critério stalinista no julgamento de um militante revolucionário. Sem apelar à cultura teórica erudita, bastaram a Graciliano a iṇtegridade de caráter e a perspicácia de grande artista.

A sensibilidade psicológica e estética do autor de Memórias não é parcial, mas multilateral, ônimoda. Aplica-se por igual aos adversários, aos inimigos, àqueles que o prenderam e o vigiam. Sem omitir detalhes chocantes de tratamento cruel, o memorialista evita o maniqueísmo e a cegueira rancorosa. Cito apenas um exemplo. Quando ainda preso no quartel no Recife, já às vésperas da transferência para o Rio de Janeiro, o comandante da unidade militar, certo capitão Lobo, aborda-o e lhe oferece dinheiro emprestado, dizendo-lhe que não se preocupasse com a restituição. Pagaria quando pudesse. Atitude estranha. $O$ capitão Lobo é um duro defensor da ditadura estado-novista, por que, no entanto, the propóe ajuda desinteressada? Sem dúvida, prevê que seu atual prisioneiro vai passar por situaçốes penosas, mas isto não seria motivo para que o auxiliasse, correndo o risco, se o seu gesto transpirasse, de se comprometer diante dos superiores hierárquicos. $\mathrm{O}$ escritor não só revelou o gesto, como citaria, muito depois, aquele militar entre seus melhores amigos.

Ora, sucede que eu também conheci o capitão Lobo, já em 1942. Ele estava, na época, em Salvador e pertencia ao Estado Maior da Região Militar. Diziase que integrava o departamento de Inteligência do Exército, o qual hostilizava os movimentos antifascistas, então em crescimento. Havia a informação sobre sua conexão com os órgáos policiais do governo estadual e que inspirava medidas repressivas contra os estudantes e outros setores participantes da campanha antifascista. Para nós, estudantes, era lobo não só no nome, mas de verdade, sem intermediações metafóricas. Por isso mesmo, foi com surpresa que reencontrei este mesmo personagem nas páginas das Memórias, visto sob aspecto oposto, como homem capaz de atitude generosa, com relação a uma pessoa acusada de comunismo e que só podia perceber do lado dos inimigos.

É precisamente a ausência de maniqueísmo que confere poder de impacto ao relato de Graciliano sobre o sistema repressivo, no qual, de súbito, se viu introduzido. Justamente pela sobriedade das adjetivaçóes, pela secura do estilo, que Alfredo Bosi aqui salientou, justamente por tudo isso adquire peso esmagador a acusação contida no quadro simplesmente realista desenhado nas Memórias. A avareza da qualificação centuplica a força de cada adjetivo, de cada caracterização. Quando Graciliano esmiuça a sujeira das condiçôes físicas ou do comportamento humano, usando magistral economia de meios léxicos e estilísticos, a sujeira nos aparece pavorosa, insuportável, infinitamente repulsiva. Recordem-se a nojeira do porão do navio, que o transportou e a outros presos políticos do Reci- 
fe ao Rio de Janeiro, a perfídia e a brutalidade dos carcereiros, a crueldade das condiçóes de sobrevivência na colônia correcional da Ilha Grande (antecipação dos campos de concentração nazistas), as perversidades sexuais praticadas por presos comuns, uns com os outros, sob a proteção de guardas coniventes pelo descaro do suborno (note-se que me refiro a perversidades sexuais e não a perversões). Se, num momento ou noutro, aparece uma face humanizada, como a do capitão Lobo ou a daquele sargento da Ilha Grande, habitualmente quebrador de pernas com as suas botinadas, sobreleva, na ambiência recriada, o choque do mundo carcerário reproduzido com minúcias incontáveis, com fragmentos inumeráveis, que se potenciam na conexão mútua, advinda do domínio da matéria pela coerência moral e pela arte.

Encerrarei com a menção do episódio da expulsão de Olga Benário Prestes e de Elisa Berger e sua posterior entrega pelo governo de Getúlio Vargas e de Filinto Müller à Gestapo. O episódio é contado por Graciliano com sufocante energia narrativa. Quis o acaso que fosse assistido por um escritor à altura, apto a refigurá-lo com sua emoção altíssima. Nesta refiguração, todavia, o narrador incide em anacronismo histórico, carregado de significação. Se me refiro ao anacronismo talvez por motivação ou viés de historiador, não o reduzo a um cochilo de Homero. Graciliano escreve que os presos políticos se uniram no protesto coletivo movidos pelo temor de que enviassem Olga e Elisa à Alemanha, onde, conforme ele próprio pensava, iriam morrer nas câmaras de gás e nos fornos crematórios. Ora, em 1937, já existiam medonhos campos de concentração na Alemanha nazista, porém não câmaras de gás e fornos crematórios. Estes foram inventados em 1940 e utilizados em larga escala somente em 1942, logo depois que Hitler e a cúpula do nazismo aprovaram formalmente a solução final para os judeus. Em 1937, embora já se soubesse do anti-semitismo raivoso dos hitleristas, ninguém fazia idéia dos extremos a que chegariam na prática do genocídio. Como é que Graciliano escreveu que os presos políticos receavam o assassinato de Olga e de Elisa em câmaras de gás e fornos crematórios, dos quais ninguém falava e que, talvez, ainda sequer estivessem na conjectura dos próprios nazistas?

Sem dúvida, a rigor, uma falha da memória. Note-se que o mesmo não ocorre, quando o memorialista observa, também no capítulo 20 , que Olga estava grávida e escreve: "Teria filho entre inimigos, numa cadeia. Ou talvez morresse antes do parto." Quando redigia sua obra, entre 1947 e 1951, Graciliano já sabia que Olga deu a luz a uma filha e que a criança sobreviveu em liberdade, resgatada do algoz nazista por uma campanha internacional. Conseguiu, contudo, distinguir o conhecimento posterior das reflexões feitas dez anos antes. Se não logrou distinção semelhante com relação às câmaras de gás e aos fornos crematórios, esta falha, em si mesma, encerra extraordinária significação, ainda mais por se tratar de memória escrupulosa e rica como a de Graciliano. É que o nazismo se associou de tal maneira àqueles e a outros horrores do ódio, que o escritor, apesar do 
respeito prioritário à exatidão dos fatos, não conseguiu estabelecer, neste caso, a dissociaçăo imposta pela cronologia e, sob a pressão difusa do imaginário coletivo, cometeu o anacronismo histórico que eu exponho aqui, não como deslize, porém como equívoco indicativo de significados mentalizados.

A bibliografia sobre vida carcerária começou há séculos e acumula, em muitos países, grande número de títulos. $\mathrm{O}$ século $\mathrm{XX}$, talvez o mais violento na história da espécie humana, deu ensejo a excepcional proliferação de relatos sobre a vida de militantes de causas ideológicas e políticas em diversos tipos de prisões. Sobrelevam, a respeito, os relatos memorialistas procedentes de sobreviventes dos campos de concentração nazistas e stalinistas. Se são importantes pelo caráter documental e informativo, de interesse peculiar para os historiadores, só algumas dessas narrativas atingem o patamar da obra literária, pelo fato de aliarem a reprodução da vivência atroz à forma criativa do ponto de vista estético.

Citaria como obras da melhor qualidade do gênero carcerário os livros $\mathrm{Se}$ questo é un nomo e I sommersi e $i$ salpati, de Primo Levi, sobrevivente do campo de extermínio nazista de Auschwitz-Birkenau. Do outro lado do confronto ideológico, colocaria, também como obra de alta literatura, o livro de Soljenitsin Um dia na vida de Ivan Denissopitch. Embora sob forma ficcional, o seu conteúdo está inteiramente fundamentado na experiência própria do autor. Primo Levi e Soljenitsin aliaram à passagem pelos campos de concentração as aptidóes de escritores talentosos.

Exatamente o mesmo pode-se e deve-se dizer de Graciliano Ramos. Suas Memórias do cárcere pertencem ao reduzido rol de obras que atravessarăo os tempos porque a arte da escrita reforçou imensamente a pungência intrínseca aos episódios e às circunstâncias expostas pelo autor e por ele padecidas.

No mais de meio século após a época em que Graciliano sofreu nas cadeias do Estado Novo, o Brasil passou por muitas mudanças que alteraram, sob diversificados aspectos, a vida do nosso povo. Mas, dentre os aspectos em nada modificados, figura a vida daqueles que o Estado aprisiona, seja por acusações de crimes políticos ou de crimes comuns. Memórias do cárcere ficará para as geraçóes futuras como obra de alta paixão moral e estética. Para as gerações do presente, salienta-se porque antecipou profeticamente as misérias das salas de tortura prodigalizadas pelo regime dos ditadores militares. A atualidade deste livro de Graciliano Ramos também se manifesta nas cadeias repugnantes, nas quais agora se amontoam, como animais, os presos comuns, sujeitos à fúria homicida dos agentes armados do Estado. Como, ainda faz pouco, se verificou no assassinato a frio de cento e onze detentos no presídio do Carandiru, em São Paulo. Se há de perdurar o interesse na leitura de Memórias do cárcere, em língua vernácula e nas traduções em outras línguas, aqui expresso a aspiração de que a realidade - a 
matéria-prima da obra - cesse definitivamente de existir no Brasil e em todos os países do mundo. Aspiraçáo de todo consentânea com este livro selecionado pelo Instituto de Estudos Brasileiros e pelo Instituto de Estudos Avançados da USP a fim de, hoje, recordar e homenagear um homem digno e sua imperecível realização artística.

Jacob Gorender é professor visitante do Instituto de Estudos Avançados da USP e autor de $A$ burguesiia brasileira (8 ed., Brasiliense, 1990) e $O$ fim da URSS - Origens e fracassos da perestroika ( 1 ed., Arual, 1993), entre outros livros. 